\title{
R Factors from Serratia marcescens
}

\author{
By R. W. HEDGES, V. RODRIGUEZ-LEMOINE* AND \\ NAOMI DATTA \\ Department of Bacteriology, Royal Postgraduate Medical School, \\ Hammersmith Hospital, London WI2 OHS
}

(Received I4 June I974; revised 22 July 1974)

\begin{abstract}
SUMMARY
$\mathrm{R}$ factors transmissible to Escherichia coli from naturally occurring strains of Serratia marcescens belonged either to compatibility groups (S and L) not represented amongst plasmids reported in other genera or to groups (C, FII, P and M) notable for their wide host range.
\end{abstract}

\section{INTRODUCTION}

In recent years, Serratia marcescens has become established in certain localities as an agent of hospital infection and cross-infection (Clayton \& von Graevenitz, 1966; Wilfert, Barrett \& Kass, I968; Davis, Foltz \& Blakemore, 1970; Wilkowske, Washington, Martin \& Ritts, 1970). In general, strains of $S$. marcescens isolated from infective lesions differ from those from other sources in being non-pigmented and antibiotic resistant (Ewing, Johnson \& David, 1962; Clayton \& von Graevenitz, 1966). Medeiros \& O'Brien (1969) and Schaefler et al. (I97I) described strains of S.marcescens, isolated from hospital patients, which were able to transfer $\mathrm{R}$ factors to Escherichia coli. Transfer of resistance to $E$. coli has also been reported from strains of $S$. marcescens isolated in France (Grimont \& Dulong de Rosnay, I972; Scavizzi, 1972; Lemosquet-Villemon, Morel \& Freymuth, 1973).

We have collected strains of $S$. marcescens, most, but not all, clinical isolates, from widely separate geographical areas; each strain was tested for antibiotic resistance and for $\mathbf{R}$ factors transmissible to E. coli KI2. The R factors were classified by compatibility in KI 2 (Datta, 1974). Our purpose was to find out how much of the antibiotic resistance observed in $S$. marcescens was determined by such $\mathrm{R}$ factors and to what extent the set of $\mathrm{R}$ factors found in $S$. marcescens is characteristic of that genus and to what extent it is shared with other bacterial genera (Coetzee, Datta \& Hedges, 1972; Datta \& Hedges, I972a; Hedges, 1974).

The R factors described by Medeiros \& O'Brien (1969) and Lemosquet-Villemon et al. (I973) were included in this study.

\section{METHODS}

Serratia marcescens. The sources of the 236 strains of S. marcescens studied are shown in Table I.

Antibiotic resistance patterns were scored using a disc method (Hedges, 1974).

Transfer of resistance to Escherichia coli $\mathrm{KI} 2$. A rifampicin-resistant mutant of E. coli KI2, $\mathrm{J62-2}$ (Hedges, 1974) was used as recipient in tests for transfer. Methods were as described by Coetzee et al. (1972).

* Present address: Department of Botany and Microbiology, University College, London, W.C. I. 
Table I. Origin of strains of Serratia marcescens

$\begin{array}{lc}\text { No. which } & \begin{array}{c}\text { No. } \\ \text { transferred } R \\ \text { factors to }\end{array} \\ \text { Donor } & \text { No. of strains } \quad \text { E.coli KI } 2\end{array}$

Dr W. A. Black, University Hospital, London, Ontario, Canada Mrs R. Dobrey, Shaughnessy Hospital, Vancouver, B.C., Canada Dr Y. Goodman, University of Alberta, Edmonton, Canada Dr F. A. Holden, University Hospital, Saskatoon, Sask., Canada Mrs C. A. Johnston, Royal Jubilee Hospital, Victoria, B.C., Canada Dr B. Brisou, Hôpital d'Instruction des Armées, Toulon, France Dr P. A. D. Grimont, Université de Bordeaux, France

Dr C. Morel, Centre Hospitalier Universitaire, Caen, France

Dr J. Borowski, University Medical School, Bialystok, Poland

Mr R. Howden, The Children's Hospital, Sheffield

Dr E. J. L. Lowbury, Birmingham Accident Hospital

Dr Soad Tabaqchali, St Bartholomew's Hospital, London

Dr Donna J. Blazevic, University of Minnesota, Minneapolis, U.S.A.

Dr J. C. Crowder, Indiana University, Indianapolis, U.S.A.

Dr G. A. Jacoby, Harvard Medical School, Boston, U.S.A.

Dr A. A. Medeiros, Peter Bent Brigham Hospital, Boston, U.S.A.

Dr J. E. Rosenblatt, V. A. Hospital (Wadsworth), Los Angeles, U.S.A.

Dr J. A. Washington, Mayo Clinic, Rochester, U.S.A.

Dr J. N. Wilfert, University of Utah, Salt Lake City, U.S.A.

\begin{tabular}{|c|c|}
\hline I9 & 2 \\
\hline I I & 0 \\
\hline 8 & 0 \\
\hline I & 0 \\
\hline 2 & 0 \\
\hline 33 & 3 \\
\hline 12 & 5 \\
\hline 2 & 2 \\
\hline 9 & 0 \\
\hline I & 0 \\
\hline 4 & 0 \\
\hline 10 & I \\
\hline 3 & 0 \\
\hline 6 & 0 \\
\hline 27 & 0 \\
\hline 20 & 16 \\
\hline 8 & 0 \\
\hline 50 & 0 \\
\hline 10 & 0 \\
\hline 236 & 29 \\
\hline
\end{tabular}

Classification of $R$ factors by compatibility was as described by Coetzee et al. (1972). Bacterial host strains were $\mathrm{J} 53$ and $\mathrm{J} 62$ (Clowes \& Hayes, 1968). Standard plasmids representing the various compatibility groups were as listed by Hedges (1974).

\section{RESULTS AND DISCUSSION}

\section{Serratia marcescens isolates}

The sources of strains are listed in Table I; most came from the U.S.A., France and Canada. We do not claim that our sample accurately reflects the world-wide distribution of $S$. marcescens from clinical sources, but it was evident that the distribution was very uneven. In some hospitals, notably in the U.S.A., infection with $S$. marcescens has presented an important clinical problem (see, for example, Davis et al. 1970).

At Hammersmith Hospital, in a dia gnostic laboratory handling some 60000 clinical cultures each year, only one or two isolations have been made per annum. A similar low incidence was found at Glasgow Royal Infirmary (Black, 1970). Information from colleagues in various parts of the country and, informally, from the Medical Research Council's Committee on Hospital Infection indicated that this was generally true in the U.K. A similar low incidence was reported to us from hospitals as far apart as Canada (personal communications from Dr F. A. Holden, University Hospital, Saskatoon, Mrs C. A. Johnston, Royal Jubilee Hospital, Victoria, and Dr D. H. Starkey, Queen Mary Veterans Hospital, Montreal) and Hong Kong (Dr C. H. Teoh-Chan, University of Hong Kong, personal communication). The variations in incidence cannot be accounted for solely by differences in methods of identification and classification of bacteria in different laboratories (Black, 1970). Isolates sent to us from the U.S.A. were identified at Hammersmith Hospital as $S$. marcescens by methods in routine daily use. We were told of at least two other cross checks of this kind 
Table 2. $R$ factors from Serratia marcescens arranged by compatibility group

$R$ factors given the same number but designated $a$ or $b$ (e.g. R476a and R476b) were derived from a single strain of $S$. marcescens. Abbreviations for resistance markers: A, ampicillin; S, streptomycin; $\mathrm{T}$, tetracycline; $\mathrm{C}$, chloramphenicol; $\mathrm{K}$, kanamycin; $\mathrm{G}$, gentamicin; Su, sulphonamide. Abbreviations for origins (see Table I): B, Dr A. A. Medeiros, Boston, U.S.A.; T, Dr B. Brisou, Toulon, France; $C$, Dr C. Morel, Caen, France; $L$, Dr S. Tabaqchali, London; $G$, Dr P. A. D. Grimont, Bordeaux, France; $\boldsymbol{O}$, Dr. W. A. Black, Ontario, Canada.

\begin{tabular}{|c|c|c|c|c|c|}
\hline R factor & $\begin{array}{c}\text { Resistance } \\
\text { pattern } \\
\text { Group L }\end{array}$ & Origin & $\mathrm{R}$ factor & $\begin{array}{l}\text { Resistance } \\
\text { pattern } \\
\text { Group FII }\end{array}$ & Origin \\
\hline $\mathrm{R}_{47 \mathrm{I}}$ & ACK & $B$ & R83ob & STCSu & $B$ \\
\hline $\begin{array}{l}\mathrm{R} 472 \\
\mathrm{R} 473\end{array}$ & A & $\begin{array}{l}B \\
B\end{array}$ & & Group M & \\
\hline $\begin{array}{l}\mathrm{R} 473 \\
\mathrm{R} 474\end{array}$ & A & $B$ & RS28 & ASTCG & $C$ \\
\hline R475 & A & $B$ & R957 & A & $O$ \\
\hline R476a & A & $B$ & R958 & A & $O$ \\
\hline R479a & A & $B$ & R930* & A & \\
\hline R83oa & SK & $B$ & & Group P & \\
\hline R83I & SK & $B$ & R839 & ASTKSu & $L$ \\
\hline R832 & A & B & R934 & ATK & $G$ \\
\hline & Group S & & & Group C & \\
\hline $\mathrm{R} 476 \mathrm{~b}$ & STSu & $B$ & R935 & ASTCKSu & $G$ \\
\hline R477 & STCKSu & $B$ & R936 & ASTCKSu & $G$ \\
\hline $\mathrm{R} 478$ & TCK & $B$ & R937 & ASTCKSu & $G$ \\
\hline R479b & STCKSu & $B$ & R938 & ASTCKSu & $G$ \\
\hline $\begin{array}{l}\text { R826 } \\
\text { R827 }\end{array}$ & $\begin{array}{l}\text { ASTCKG } \\
\text { ASTCKG }\end{array}$ & $T$ & & & \\
\hline R828 & ASTCKG & $T$ & & & \\
\hline R829 & STCK & $B$ & & & \\
\hline
\end{tabular}

* R930 was derived from a strain of $S$. liquefaciens isolated at Hammersmith Hospital.

(MRC Committee on Hospital Infection and D. H. Starkey, personal communication) with similar results.

Most of the strains (224) were from clinical material; among these only 13 produced pigment. [Pigment was observed in cultures on nutrient agar (Oxoid No. 2 broth, solidified with Oxoid New Zealand agar); special media to encourage pigment production were not used.] The remaining 12 strains, provided by Dr B. Brisou, Hôpital d'Instruction des Armées, Toulon, France, were isolated from river and sea water; all of these were pigmented.

Antibiotic resistance. Most strains (75\%) were resistant to polymyxin B, and 70 strains $(30 \%)$ were resistant to no other drug besides polymyxin B; I 19 strains $(50 \%)$ were resistant to ampicillin, and of these, 50 (20\% of the total) were also resistant to carbenicillin; $42 \%$ were tetracycline resistant, 19\% kanamycin resistant and $16 \%$ chloramphenicol resistant.

These figures are from tests in our laboratory: information from the laboratories where the strains were isolated indicated that larger numbers (the proportion cannot be accurately estimated) had been resistant to more antibiotics on first isolation. Spontaneous loss of resistance suggests the presence of plasmids which were unstable in their host bacteria. Medeiros \& O'Brien ( 1969 ) recognized a high rate of spontaneous loss of multiple resistance in their $S$. marcescens isolates, which we have confirmed both with their strains and others.

\section{$R$ factors transferred to Escherichia coli $\mathrm{KI} 2$}

The I 66 strains of $S$. marcescens which were resistant to some drug or drugs other than polymyxin B were tested for transfer of resistance to $E$. coli K I 2. Twenty-seven R factors were 
detected; all came from strains isolated from clinical material. This number includes I 5 whose transfer had been demonstrated by Medeiros \& O’Brien (1969). In addition, Dr C. Morel provided us with eight $\mathrm{R}$ factors, derived from strains of $S$. marcescens, already transferred to $E$. coli KI 2 (Lemosquet-Villemon et al. 1973). The R factors studied are listed in Table 2.

\section{Compatibility groups of $R$ factors}

Among the $\mathrm{R}$ factors studied were the prototypes of two new groups, $\mathrm{S}$ and $\mathrm{L}$. Plasmids of groups $S$ and $L$ have, so far, never been found in naturally occurring bacteria other than S. marcescens.

Group L. All the R factors of group L came from one source, the Peter Bent Brigham Hospital, Boston, U.S.A. They conferred three different patterns of resistance and were incompatible with one another but compatible with plasmids of all other defined groups.

Group S. Plasmids of group $S$ were temperature sensitive in some component of their transfer property (Rodriguez-Lemoine, Jacob, Hedges \& Datta, 1975). They occurred in strains isolated in Boston and Toulon. They determined various resistance patterns; in those from France, this included resistance to gentamicin.

Other groups. RS28, taken as the exemplar of the R factors identified by LemosquetVillemon et al. (1973), belonged to group M. R factors from $S$. marcescens from Ontario also belonged to this group. A strain of Serratia liquefaciens (Ewing, Davis \& Tife, 1972) isolated at Hammersmith Hospital also carried an R factor of group M.

Four R factors from strains of $S$. marcescens sent from Bordeaux belonged to group $\mathrm{C}$. Although conferring chloramphenicol resistance, these plasmids did not determine the production of chloramphenicol transacetylase (Shaw, 197I; Nagai \& Mitsuhashi, 1972; Mrs L. C. Sands, personal communication).

One R factor from Boston belonged to group FII and two, one from Bordeaux and one from London, belonged to group $P$.

\section{The $R$ factor set for $S$. marcescens}

The plasmids from the Peter Bent Brigham Hospital belonged to three compatibility groups, two of which had not previously been described. In conformity with Schaefler $e t$ al. (197I), we believe that this indicates that the $S$. marcescens population of this hospital is ecologically isolated from other Serratia populations, including that in Boston City Hospital. The ecological isolation, however, is evidently not complete since in the same hospital, one strain of $S$. marcescens carried an R factor of group FII, very similar to plasmids isolated from several other genera (Harada, Suzuki, Kameda \& Mitsuhashi, 1960), and R factors of group S were also identified in $S$. marcescens strains from Toulon.

The other $\mathbf{R}$ factors identified belonged to groups $\mathrm{P}, \mathrm{C}$ and $\mathrm{M}$, which are known to have unusually wide host ranges among bacterial genera (Datta et al. I97I; Datta \& Hedges, I972 $a, b$; Hedges, Datta, Coetzee \& Dennison, I973; Olsen \& Shipley, 1973).

Thus the R factor set of $S$. marcescens subdivides into plasmids whose natural range seems to be limited to this species and plasmids with a markedly promiscuous distribution.

We are very grateful to all those who sent us strains of $S$. marcescens and information about its incidence in various environments, and to Mrs L. C. Sands, Department of Medicine, University of Miami, U.S.A., for testing $\mathrm{R}^{+}$strains for production of chloramphenicol transacetylase. 


\section{REFERENCES}

Black, W. A. (1970). Search for Serratia. Journal of Clinical Pathology 23, 378.

Clayton, E. \& von Graevenitz, A. (1966). Nonpigmented Serratia marcescens. Journal of the American Medical Association 197, 1059-1064.

Clowes, R. C. \& Hayes, W. (1968). Experiments in Microbial Genetics. Oxford and Edinburgh: Blackwell Scientific Publications.

Coetzee, J. N., Datta, N. \& Hedges, R. W. (1972). R factors from Proteus rettgeri. Journal of General Microbiology 72, 543-552.

DatTa, N. (1974). Epidemiology and classification of plasmids. In Booklet 60502, American Society for Microbiology (in the Press).

Datta, N. \& Hedges, R. W. (1972 a). Host ranges of R factors. Journal of General Microbiology 70, 453-460.

Datta, N. \& Hedges, R. W. (1972b). R factors identified in Paris, some conferring gentamicin resistance, constitute a new compatibility group. Annales de l'Institut Pasteur 123, 879-883.

Datta, N., Hedges, R. W., Shaw, E. J., Sykes, R. B. \& Richmond, M. H. (1971). Properties of an R factor from Pseudomonas aeruginosa. Journal of Bacteriology 108, 1 244-1 249.

Davis, J. T., Foltz, E. \& Blakemore, W. S. (1970). Serratia marcescens; a pathogen of increasing importance. Journal of the American Medical Association 214, $2190-2192$.

Ewing, W. H., Davis, B. R. \& Tife, M. A. (1972). Biochemical characterization of Serratia liquefaciens and Serratia rubidaea. Publication No. HSH 73-8209, Department of Health, Education and Welfare, U.S.A.

Ewing, W. H., Johnson, J. G. \& David, B. R. (1962). The Occurrence of Serratia marcescens in Nosocomial Infections, pp. I-I3. U.S.A.: Department of Health, Education and Welfare.

Grimont, P. A. D. \& Dulong De Rosnay, H. L. C. (1972). Numerical study of 60 strains of Serratia. Journal of General Microbiology 72, 259-268.

Harada, K., Suzuki, M., Kameda, M. \& Mitsuhashi, S. (1960). On the drug resistance of enteric bacteria. II. Transmission of the drug resistance among Enterobacteriaceae. Japanese Journal of Experimental Medicine 30, 289-299.

Hedges, R. W. (1974). R factors from Providence. Journal of General Microbiology 81, I71-181.

Hedges, R. W., Datta, N., Coetzee, J. N. \& Dennison, S. (1973). R factors from Proteus morganii. Journal of General Microbiology 77, 249-259.

Lemosquet-Villemon, M., Morel, C. \& Freymuth, F. (1973). Étude d'un charactère de résistance à la gentamicine. Pathologie et biologie 21, 227-232.

Medeiros, A. A. \& O'Brien, T. F. (1969). Contribution of R factors to the antibiotic resistance of hospital isolates of Serratia. In Antimicrobial Agents and Chemotherapy - I968, pp. 30-35. Washington, D.C: American Society for Microbiology.

NAGAI, Y. \& Mrtsuhashi, S. (1972). New type of R factors incapable of inactivating chloramphenicol. Journal of Bacteriology rog, I-7.

Olsen, R. H. \& Shipley, P. (1973). Host range and properties of the Pseudomonas aeruginosa R factor Ri822. Journal of Bacteriology $113,772-780$.

Rodriguez-Lemoine, V., JACOB, A. E., Hedges, R. W. \& Datta, N. (1975). Thermosensitive production of their transfer system by group S plasmids. Journal of General Microbiology 86, I I I-I 14 .

SCavizzi, M. R. (1972). Existence de deux caractères transférables de résistance aux tetracyclines. Annales de l'Institut Pasteur 122, 3-17.

Schaefler, S., Winter, J., Catelli, A., Greene, J. \& Toharski, B. (197I). Specific distribution of R factors in Serratia marcescens strains isolated from hospital infections. Applied Microbiology 22, 339-343.

Shaw, W. V. (1971). Comparative enzymology of chloramphenicol resistance. Annals of the New York Academy of Sciences 182, 234-242.

Wilfert, J. N., BARrett, F. F. \& KASs, E. H. (1968). Bacteraemia due to Serratia marcescens. New England Journal of Medicine 279, 286-289.

Wilkowske, C. J., Washington, J. A., Martin, W. J. \& Ritts, R. E. (1970). Serratia marcescens. Biochemical characteristics, antibiotic sensitivity patterns and clinical significance. Journal of the American Medical Association 214, 2 I 57-2 162. 